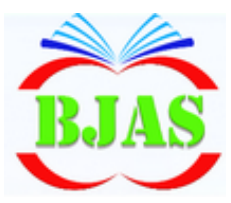

Available online at http://journal.bajas.edu.iq

College of Agriculture, University of Basrah

DOi:10.21276/basjas

Basrah

Journal of

Agricultural

Sciences

E-ISSN: 2520-0860

ISSN 1814 - 5868 Basrah J. Agric. Sci., 32(Spec Issue): 258-265, 2019

\title{
The Effect of Thidiazuron on Callus and in vitro Shoots Development of Date Palm (Phoenix dactylifera L.) cv. Barhee
}

\author{
Ahmed Z. Al-Asadi ${ }^{1}$, Aqeel H. Abdulwahid ${ }^{*}$ \& Ahmed M.W. Al-Mayahi \\ ${ }^{1}$ Department of Horticulture and Landscape Design, College of Agriculture, University of \\ Basrah, Iraq \\ ${ }^{2}$ Date Palm Research Centre, University of Basrah, Basrah Iraq \\ *Corresponding author e-mail: aqeelhadi6@gmail.com
}

Received 7 June 2019; Accepted 2 September 2019; Available online 10 Octobr 2019

\begin{abstract}
Date palm (Phoenix dactylifera L.) is one of the most important fruit trees spread in southern Iraq, but because of many circumstances decreased their numbers significantly, the propagation of date palm by tissue culture was the best solution for repreparation of the problem as it was previously, because propagation is accelerated. Summarizes the working paper in an attempt to find the optimal concentration of thidiazuran (TDZ) $\left(0.0,0.5\right.$ and 1.0) $\mathrm{mgl}^{-1}$, in production of callus and regeneration of shoots, at different times of initial and callus culturing in medium budding. The results showed that the concentration of $(0.5) \mathrm{mgl}^{-1}$ was optimal in all traits under study.
\end{abstract}

Key words: Phoenix dactylifera, Thidiazuron (TDZ), Callus, Shoot multiplication, browning, in vitro.

\section{Introduction}

Date palm (Phoenix dactylifera $\mathrm{L}$ ) is one of the most important fruit trees evergreens in many countries of the world, the originate of the date palm is believed in the Arabian Gulf and it is likely to have originated in southern Iraq (Wrigley, 1995).

Traditional method of date palm multiplication is achieved by offshoots. The limited availability of offshoots makes this traditional propagation method insufficient, especially since some cultivars do produce a few offshoots for a certain period in the life time of a young palm tree, slow propagation rate, the offshoots are also a source of transportation of diseases and insects (Gueye et al.., 2009). Tissue culture techniques have become a common and alternative method for vegetative propagation of date palm in recent years. Especially as date palm responds to modern biotechnlogy applications (Jasim et $a l ., 2009)$. The benefit of using this technique is the production of true to type, disease free. Moreover production is on a commercial scale (Al-Wasel, 2001; Ahloowalia et al., 2004). Thiaduzuron (TDZ) (N-phenyl-N- 1, 2, 3-thiadiazol-5-ylurea). Cappelletti et al. (2016) displayed that the addition of both 0.2 $\mathrm{mg} \mathrm{l}^{-1}$ and $0.5 \mathrm{mg} \mathrm{l}^{-1}$ of TDZ in the medium led to improved callus formation in blueberry. The formation of shoot is stimulated in a wide range of plant species chestnut, mulberry, white pine, banana Pinus and strawberry (San-Jose et al., 2001; Chitra \& Padmaja 2005; Tang \& Newton, 2005; Gubbuk and 
Pekmezci, 2006; Jericó et al., 2011; Cappelletti et al., 2016). As for studies on date palms, Al-Mayahi (2014) explained that the transfer of callus to the multiplication medium supplemented with $0.5 \mathrm{mg} . \mathrm{l}^{-1} \mathrm{TDZ}$, recorded the best response (66.67\%), with the highest rate of number of shoots 18.2 shoot after 24 weeks from culturing. Although the progress made in the cultivation of plant tissues, there are many problems and difficulties in propagation of date palm in this way. The composition of the growth media is of great importance in the growth and development of cultured plants. This reflects the success of propagation of this technique. A statistics of date palm indicate a decrease in the numbers of this tree in all areas of palm growing in Iraq, especially in the province of Basrah because of the conditions that have led to the neglect the farmers to orchards, as well as the scarcity of irrigation water and increase salinity. The aim of this study is focusing on the effect of thiaduzuron ( TDZ) on the growth and development of callus and regenerated buds of date palm Barhee cultivar

\section{Materials \& Methods}

The experiments for this study were carried out in tissue culture laboratory for Date Palm Research centre in University of Basrah.

1-Effect of different concentrations of Thiaduzuron (TDZ) on growth primary callus at different times of callus culturing

Callus of date palm cv. Barhee obtained from the cultivating the quarters of apical buds on medium composed of (MS) (Murashig \& Skoog, 1962), with additional $30 \mathrm{mg} \mathrm{l}^{-1} \alpha-$ naphthalene acetic acid (NAA),3mg $\mathrm{l}^{-1}$ isopentenyl adenine (2iP) and $2 \mathrm{~g} \mathrm{l}^{-1}$ activated charcoal, under complete darkness at $27 \pm 2$ ${ }^{\circ} \mathrm{C}$. The callus was divided and re-culture into jars contain $100 \mathrm{mg}$ MS media with the addition of the following chemicals (mg. $\left.\mathrm{l}^{-1}\right)$ as sodium phosphate (170), thiamine (0.5), adenine sulfate (40), (NAA) 10 and cytokinin (2iP) $1.5 \mathrm{mg} \mathrm{l}^{-1}$. TDZ has been added with different concentrations (0.0, 0.5 and 1.0) $\mathrm{mg} . \mathrm{l}^{-1}$, to examine its effect on the growth of initial callus after four, six and eight weeks, which was adopted as an indicator of growth according to the method mentioned by (Jasim \& Saad, 2011).

\section{2-Test of Thiaduzuron (TDZ) on stimulation of primary callus tissue to budding}

A $100 \mathrm{mg}$ of callus were transferred to a jar that contains MS media with the additional growth regulators $1 \mathrm{mg} . \mathrm{l}^{-1} \mathrm{NAA}$ and $3 \mathrm{mg} . \mathrm{l}^{-1}$ 6-benzylamino purine (BA) and activated charcoal at $500 \mathrm{mg} . \mathrm{l}^{-1}$. TDZ was added at concentrations of $0.0,0.5$ and $1.0 \mathrm{mg} . \mathrm{l}^{-1}$. Six replicates were used for each treatment. The cultures were incubated at a temperature of 27 $\pm 1^{\circ} \mathrm{C}$, a light intensity of 1000 lux with a rate of 16 light hours/day followed by 8 hours of darkness, The following measurements were taken after 10,12 and 14 weeks of callus culturing. i- Percentage of callus tissue budding, ii- percentage of browning.

\section{3-Test The thiaduzuron (TDZ) on the growth and multiplication of adventitious buds}

Several concentrations of Thiaduzuron (TDZ) $\left(0.0,0.5\right.$ and 1.0) $\mathrm{mgl}^{-1}$ were tested in order to investigate their effect on the growth of adventitious buds and their multiplication of date palm cv. Barhee grown in vitro, The buds were divided from two - three buds and re-culture in MS media with addition $0.5 \mathrm{mg}$ $\mathrm{l}^{-1} \mathrm{NAA} 0.5 \mathrm{mg} \mathrm{l}^{-1} \mathrm{BA}, 0.5 \mathrm{mg} \mathrm{l}^{-1}$ kinetin (K) and $0.5 \mathrm{~g} \mathrm{l}^{-1}$ activated charcoal $0.5 \mathrm{mg} \mathrm{l}^{-1}$ (AlMayahi, 2016). The measurements were taken after 4,6 and 8 weeks of culturing, included 
1) Number of buds. 2) Number of shoots. 3) Weight of buds.

\section{Experimental design and statistical analysis}

The experiment was design in Completely Randomized Design (C.R.D). Using GenStat software. Differences were compared using the least significant difference (L.S.D) at the $5 \%$ probability level, depending on (Snedecor \& Cochran, 1989).

\section{Result \& Dissection}

The results in fig. (1) shown significant effect of Thiaduzuron on the weight of callus and It is clear that increase the weight of callus by increasing the duration of callus culture and the concentration of TDZ, The weight after four weeks was increased in the treatment of $1 \mathrm{mgl}^{-1}$ TDZ. Which gave a higher weight reached $1.58 \mathrm{~g}$ which no significant difference with the treatment $0.5 \mathrm{mg}^{-1} \mathrm{l}^{-1}$ while a significant difference with control treatment. After six weeks of callus culture, there was a significant increase in the weight of the callus, which reached $5.94 \mathrm{~g}$ and $5.63 \mathrm{~g}$ for both treatments 0.5 and $1 \mathrm{mg} \mathrm{l}^{-1}$ respectively, which indicated a significant difference compared to control treatment $3.12 \mathrm{~g}$. after 8 weeks of culture, the weight of the callus increasing reached the highest weight reached $5.63 \mathrm{~g}$ and $5.49 \mathrm{~g}$ for the treatments 0.5 and 1 $\mathrm{mg} \quad \mathrm{l}^{-1}$ respectively, which revealed a significant difference compared to control treatment.

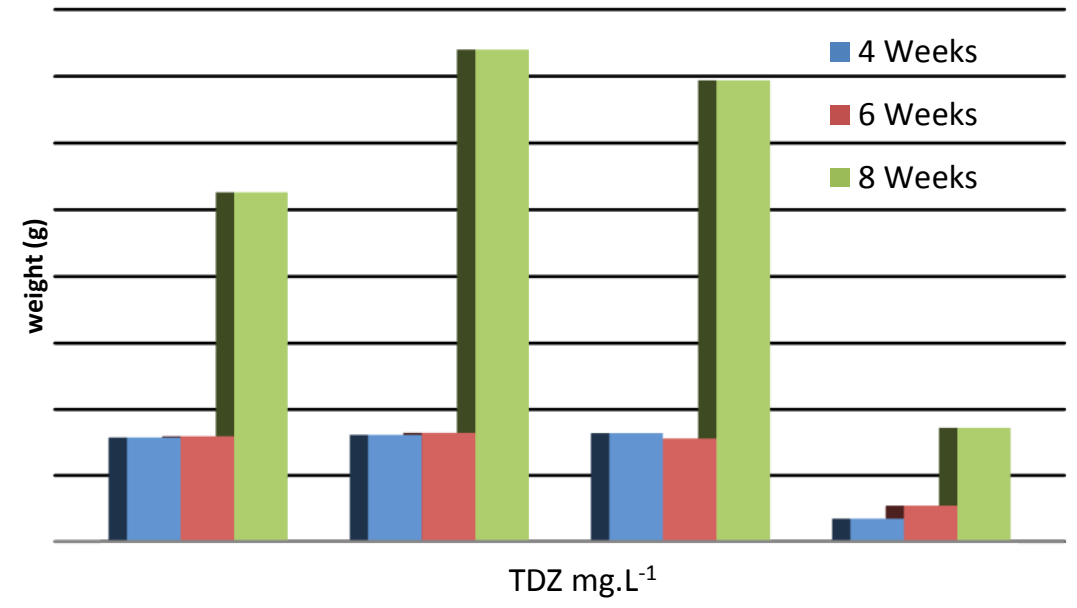

Fig. (1): Effect of TDZ on callus fresh weight.

Fig. (2) exhibited the effect TDZ concentrations on callus browning percentage. It is clear from the figure that the highest percentage obtained in the control treatment was $8.3 \%$ followed by the treatment of $1 \mathrm{mg} \mathrm{l}^{-}$ ${ }^{1}$, whiles the treatment of $0.5 \mathrm{mg} \mathrm{l}^{-1}$, gave a lower percentage of browning reach $1.9 \%$.
Fig. (3) presented the percentage of budding of callus tissue, that the highest percentage of callus budding at treatment $0.5 \mathrm{mg}^{-1}$ was reached $40 \%$ and significantly different with two other treatments $1 \mathrm{mg} \mathrm{l}^{-1}$ and control treatment 33 and $28 \%$, respectively. 


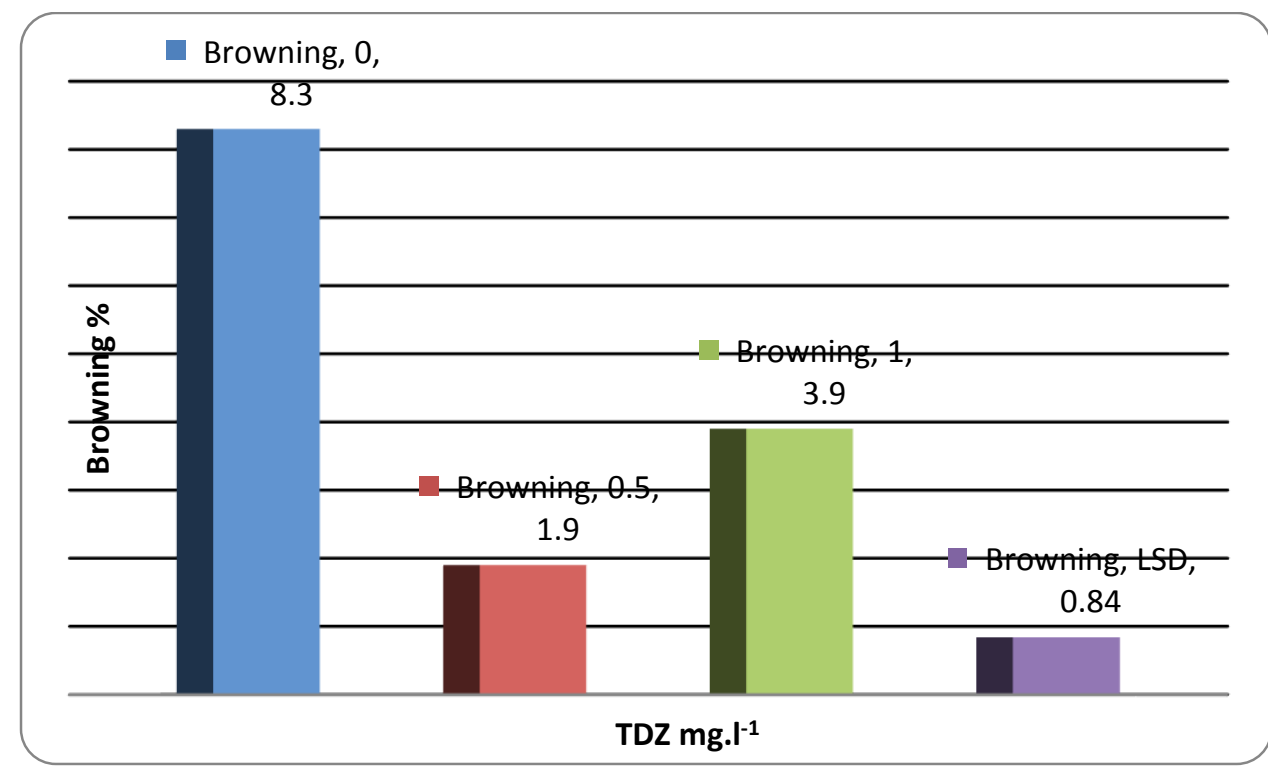

Fig. (2): Effect of TDZ on callus browning percentage.

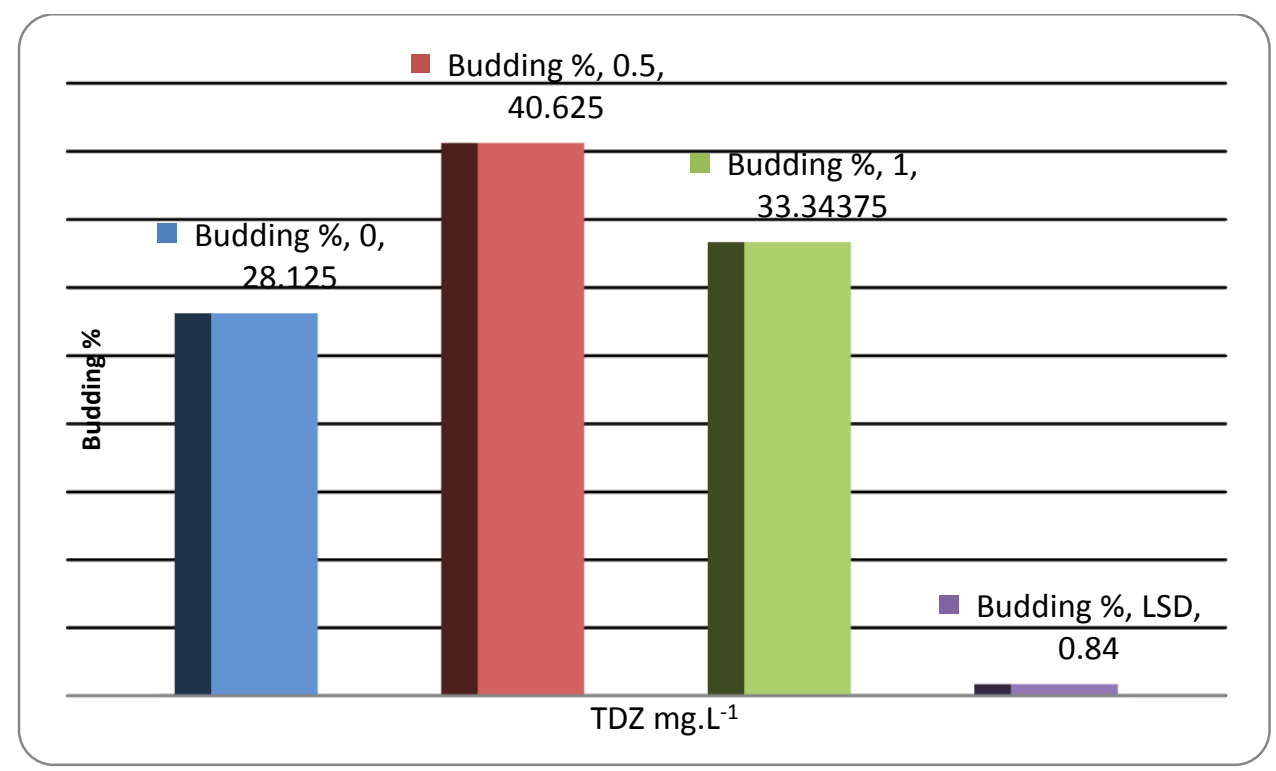

Fig. (3): Effect of TDZ on a response percentage of callus on budding.

The effect of Thiaduzuron on the weight of buds during the culturing period. There was no significant difference after 10 weeks of cultivation in the weight of buds. The highest weight recorded by the concentration of $1 \mathrm{mg}$. $\mathrm{1}^{-1}$ was $7.76 \mathrm{~g}$ then $7.18 \mathrm{~g}$ in $0.5 \mathrm{mg} . \mathrm{l}^{-1}$ treatment. Buds weight were increased after 12 weeks of culturing, the two treatment 0.5 and $1 \mathrm{mg} \mathrm{l}^{-1}$ recorded $10.58 \mathrm{~g}$ and $10.54 \mathrm{~g}$ respectively, which displayed a significant difference compared to control treatment. Thereafter, a slight decrease in weight it has notes at 14 weeks after cultured, treatment of $0.5 \mathrm{mg}^{-1}$ recorded a weight reached $10.43 \mathrm{~g}$ with no significant difference with control treatment. The decrease of buds weight may be due to an increase in the number of buds on the area unit which have led to competition 


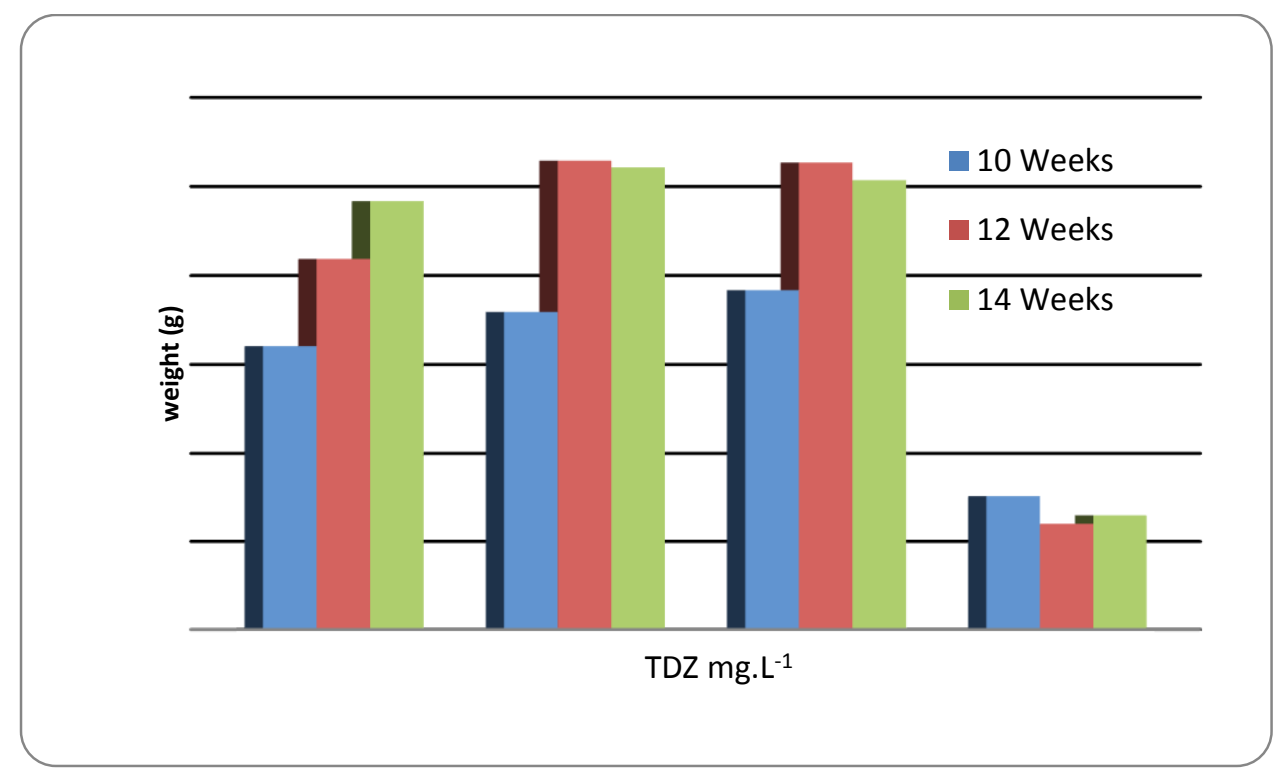

Fig. (4): Effect of TDZ on buds weight.

for available food resources, thus causing a decline in their growth as illustrated by Fig. (4). Fig. (5) indicated significant differences in the number of shoots after 10 weeks were gave 13 buds at $0.5 \mathrm{mgl}^{-1}$ which showed significant difference from $1 \mathrm{mg} \mathrm{l}^{-1}$ concentration 10.67 buds which did not differ significantly from the control treatment, which recorded 9 buds, and then noted a linear increase with the increased time with the highest number of buds at treatment 0.5

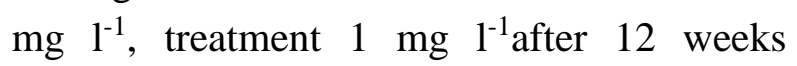

reached 16.67 and 15 , respectively, The highest number of shoots after 14 weeks of culturing was 19 bud at $0.5 \mathrm{mgl}^{-1}$ and a significant difference from the treatment $1 \mathrm{mg}$ $\mathrm{l}^{-1}$, which in turn did not differ significantly from the control treatment.

The effect of Thidiazuron on shoots number was no significant difference in shoots number during the first and second dates (10 and 12 weeks).

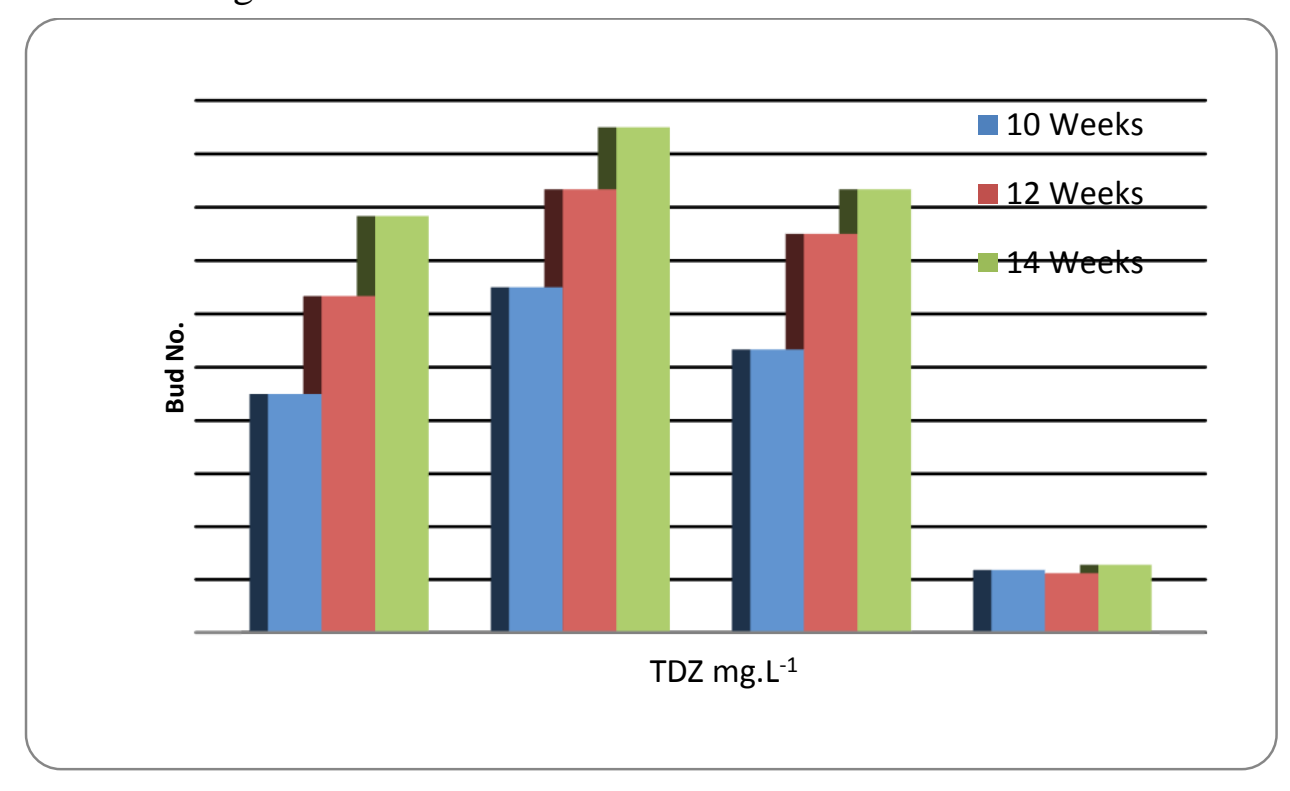

Fig. (5): Effect of TDZ on Buds Number. 


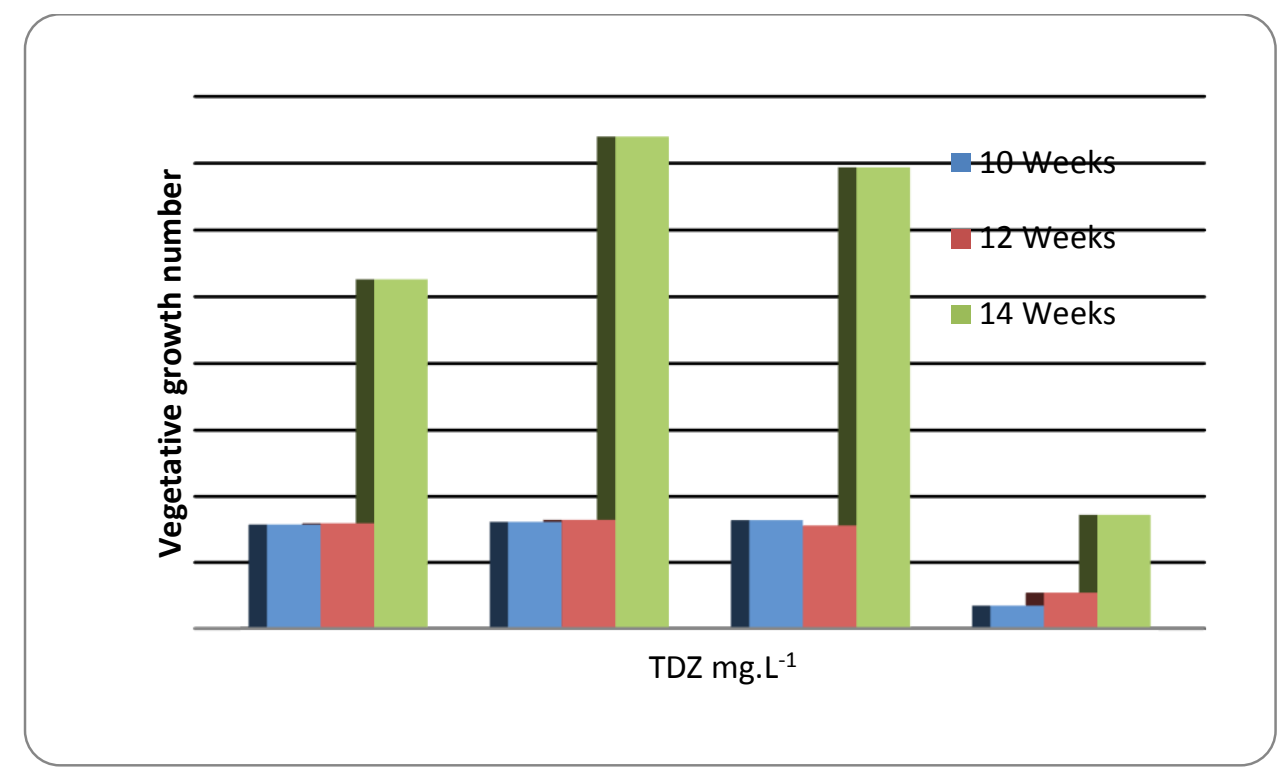

Fig. (6): Effect of Thidiazuron vegetative growth number.

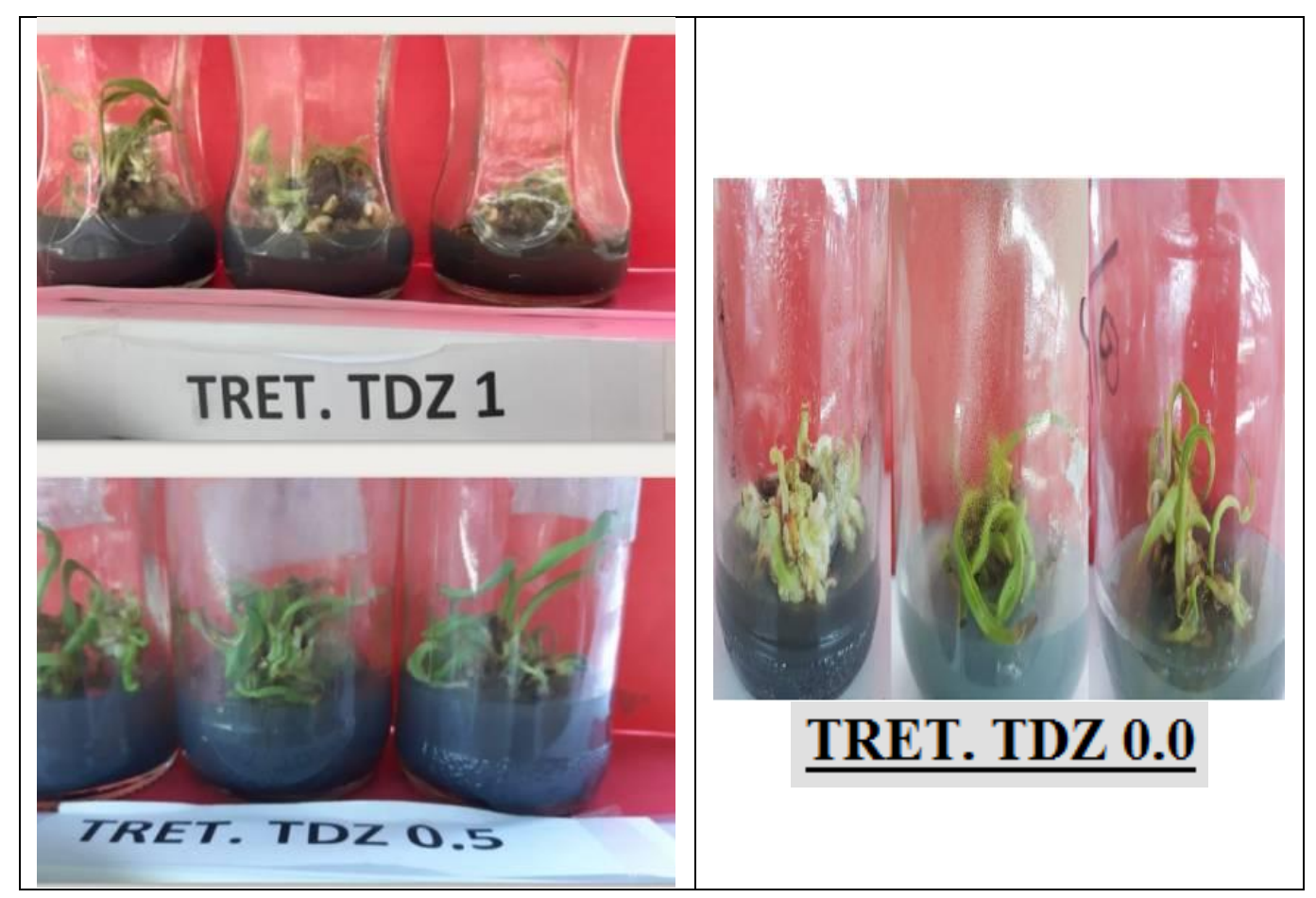

Fig. (7): Multiple shoot proliferation of date palm cv.Barhee in vitro under different concentration of TDZ.

As well as, statistical analyzes did not show any significant differences between different concentrations on the number of shoots. However, the highest regeneration in shoot number was recorded on the third date after 14 weeks of re-culture. The treatment was 0.5 $\mathrm{mg}^{-1}$ gave a high number of shoot growths 
which reached 37 shoot growth followed by the treatments 1 and $0 \mathrm{mg} \mathrm{l}^{-1}$ (Figs. $6 \& 7$ ).

The effects of Thiaduzuron on callus fresh weight is a result of its effectiveness in stimulating the division of cells and then increase the weight by stimulating the building of proteins, enzymes and the RNA molecule inside the cell, which is reflected on the increase in cells size, as a result of the transfer of water and food to them. Thiadozorone works to balance or modify the internal levels of auxins and cytokinins within cells, which it is reflected on the increase the number of lateral buds and their weight as a result of the increase of lateral growth, thiadiazurone also reduces the disruption of chlorophyll and protein, and stimulation the enzymes of photosynthesis, thus increasing the number of buds and shoots length (Abbasi et al., 2011; Thomas, 2003; Casanova et al., 2004; Al-Mayahi, 2014).

\section{Conclusion}

It seems from this paper the advantage of using Thiaduzuron and consideration as a suitable hormone at $0.5 \mathrm{mg} . \mathrm{l}^{-1}$ to give a high weight of callus of Barhee date palm cultivar and increased the number of buds and increase the shoot development.

\section{Acknowledgements}

The authors thanks Date Palm Research Centre, Tissue Culture Laboratory, University of Basrah, Iraq, for providing laboratory space and the other facilities used to conduct this work.

\section{References}

Abbasi, H.; Zeb, A.; Xu L.L. \& Wei, Y.H. (2011). Thidiazuron: A multidimensional plant growth regulator. Afr. J. Biotechnol., 10(45): 8984- 9000
Ahloowalia, B.S.; Prakash, J.; Savangilkar, V.A. \& Savangilkar, C. (2004). Plant tissue culture. Low cost of option for tissue culture technology in developing countries .proceeding of a technical Meeting , Organized by the Joint FAO . IAEA. 3-10.

Al-Mayahi, A.M.W. (2014). Thidiazuron induced in vitro bud organogenesis of the date palm (Phoenix dactylifera L.) cv. Hillawi. Afr. J. Biotechnol., 13(35): 35813590 .

Al-Mayahi. A.M.W. (2016). Effect of red and blue light emitting diodes "CRB-LED" on in vitro organogenesis of date palm (Phoenix dactylifera L.) cv. Alshakr. World J. Microbiol. Biotechnol., 32: 160 https://doi.org/10.1007/s11274-0162120-6.

Al-Wasel, A.S. (2001). Phenotypic comparison of tissue culture derived and conventionally propagated by offshoots date palm (Phoenix dactylifera L.) cv. Barhee trees 1-Vegetative characteristics. J. K.S.U. Agric. Sci., 13(1): 65-73.

Cappelletti, P.; Sabbadini, S. \& Mezzetti, B. (2016). The use of TDZ for the efficient in vitro regeneration and organogenesis of strawberry and blueberry cultivars. Sci. Hor., 207: 117-124.

Casanova, E.; Valdes, A.E.; Fernandez, B.; Moysset, L., \& Trillas, M.I. (2004). Levels and immune localization of endogenous cytokinins in thidiazuron -induced shoot organogenesis in carnation. J. Plan Physiol., 161(1): 95-104.

Chitra, D.S.V. \& Padmaja G (2005). Shoot regeneration via direct organogenesis from in vitro derived leaves of mulberry using thidiazuron and 6-benzylaminopurine. Sci. Hortic., 106(4): 593-602 
Al-Asadi et al. / Basrah J. Agric. Sci., 32 (Special Issue): 258-265, 2019

Gubbuk H. \& Pekmezci, M. (2006). In vitro propagation of banana (Musa spp.) using thidiazuron and activated charcoal. Acta Agr. Scand. B S. P., 56(1): 65-69.

Gueye, B.; Morcillo F.; Collin M.; Gargani D. \& Overvoorde, P. (2009). Acquisition of callogeniccapacity in date palm leaf tissues in response to 2,4-D treatment. Plant Cell Tiss. Organ Cult., 99: 35-45.

Jasim, A.M. \& Saad, A.A. (2001). Effect of some media component on growth and somatic embryos formation and germination of date palm (Phoenix dactylifera L.) cultured in vitro. Basrah Date Palm Res. J., 1: 1-7.

Jasim, A.M.; Al-Mayahi A.M.W. \&. Attaha A.H.M. (2009). Propagation of four rare cultivars of date palm (Phoenix dactylifera L.) by tissue culture techniques. Basrah J. Date Palm Res., 8(1): 72-99.

Jericó1 B.B.; Lourdes, I.A.; Lázaro, S.V.; José, C.M. \& Nancy, S.B. (2012). In vitro regeneration of Pinus brutia Ten. var. Edarica (Medw.) through organogenesis. Afr. J. Biot., 11(93): 15982-15987
Murashig, T. \& Skoog, F. (1962). A revised medium for rapid growth and bioassays with tobacco tissue cultures Physiol. Plant, 15: 473- 497.

San-Jose, M.C.; Ballester, A. \& Vieitez, A.M. (2001). Effect of thidiazuron on multiple shoot induction and plant regeneration from cotyledonary nodes of chestnut. J. Hort. Sci. .Biotechnol., 76(5): 588-595.

Snedecor, G.M. \& W.G. Cochran, (1989). Statistical Methods. $1^{\text {st }}$ ed., Iowa State University, Ames:503pp.

Tang, W. \& Newton R.J. (2005). Plant regeneration from callus cultures derived from mature zygotic embryos in white pine (Pinus strobus). Plant Cell Rep., 24: 1-9.

Thomas, T.D. (2003). Thidiazuron induced multiple shoot induction and plant regeneration from cotyledonay explants of mulberry. Biol. Plant. 46: 529-533

Wrigley, G. (1995). Date Palm Pp: 399-403. In: Smart, J. and Simonds, N.W. (Eds.). Evolution of Crop Plants $2^{\text {nd }} e d$. Longman, London: 496pp. 